\title{
EVALUASI SIFAT MEKANIK HIGH DENSITY POLYETHYLENE YANG DIISI SERAT BATANG PISANG DAN PARTIKEL ZEOLIT ALAM
}

\author{
Hardiman Nurcahyanto ${ }^{1}$
}

\begin{abstract}
ABSTRAK
Pohon pisang yang merupakan limbah, dimanfaatkan pelepahnya untuk diambil seratnya guna pembuatan komposit. Pada penelitian ini dilakukan untuk mengetahui potensi sifat mekanik serat batang pisang yang dikombinasikan dengan serbuk mineral Zeolit, dan HDPE (Hight density polyethylene) sebagai matrik komposit ini. Untuk mengetahui sifat mekanik pada komposit dilakukan uji tarik ASTM D 638-02 dan DENT. Sebelum dijadikan komposit, serat dilakukan treatment menggunakan larutan $\mathrm{NaOH}$ 5\% selama 2 jam dan dikeringkan pada suhu kamar selama 3-4 hari. Metode pembuatan komposit yaitu menggunakan injeksi molding (injection moulding) yang sebelumya dilakukan penyerbukan semua bahan agar tercampur sempurna dengan variasi komposisi serat zeolit berturut-turut $2 \%: 3 \%, 3 \%: 2 \%, 4 \%: 1 \%$ dan ligamen dengan variasi panjang $6 \mathrm{~mm}, 8 \mathrm{~mm}$, dan $10 \mathrm{~mm}$ untuk spesimen uji. Hasil yang didapatkan komposit pengujian komposit dalam penelitian ini berupa uji kekuatan tarik menurut standart ASTM D 638-02 dan DENT. Hasil pengujian tarik dengan standart ASTM D 638-02 didapat nilai tertinggi maximum force, elongation, modulus young, dan tensile strength terdapat pada HDPE murni dengan nilai maximum force 678,90 Newton, elongation $16 \%$, modulus young $514,50 \mathrm{~N} / \mathrm{mm}^{2}$ dan tensile

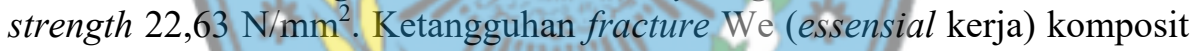
terdapat pada spesimen komposit serat 4\% zeolit 1\% dengan nilai 203,27 $\mathrm{kJ} / \mathrm{m}^{2}$. Dapat disimpulkan komposit serat $4 \%$ zeolit $1 \%$ memiliki hubungan linier we (essensial kerja) yang baik dibandingkan pada komposit lainnya.
\end{abstract}

Kata Kunci: Serat Batang Pisang, Zeolit, HDPE, Injection Molding, Uji Tarik, Uji SEM.

PENDAHULUAN

Komposit banyak sekali digunakan karena strukturnya yang kuat namun memiliki berat yang ringan. Diantaranya sebagai bahan dasar bodi mobil, bahkan pesawat yang membutuhkan struktur bahan yang kuat namun memiliki berat yang ringan. Komposit merupakan bahan yang terdiri atas fase penguat dan matriks. Hal ini yang menyebabkan komposit memiliki struktur yang kuat namun memiliki berat yang cukup ringan, sehingga sangat cocok digunakan sebagai bahan dasar berbagai macam bahan baku industri (Clareyna dan Mawarani, 2013).

${ }^{1}$ PT. Ungaran Sari Garment, J1 P Diponegoro No 235 Ungaran Kab Semarang 50512 
Material komposit adalah material yang terbuat dari dua bahan atau lebih yang tetap terpisah dan berbeda dalam level makroskopik selagi membentuk komponen tunggal. Bahan komposit adalah suatu jenis bahan baru hasil rekayasa yang terdiri dari dua atau lebih bahan dimana sifat masing-masing bahan berbeda satu sama lainnya baik itu sifat kimia maupun fisiknya dan tetap terpisah dalam hasil akhir bahan tersebut (bahan komposit). Karena karakteristik pembentuknya berbeda-beda maka akan diperoleh suatu material baru yang lebih baik dari material pembentuknya. Material pembentuk komposit ada 2, yaitu penguat (reinforcement) dan pengikat (matriks). Sifat komposit bahan sangat dipengaruhi oleh sifat dan distribusi unsur penyusunnya, serta interaksi antara keduanya. Parameter yang lain yaitu bentuk, ukuran orientasi dan distribusi dari penguat dan sifat-sifat matriksnya (Kartini dkk, 2002).

Salah satu dari plastik sintetis adalah HDPE. HDPE memiliki nilai kuat tarik sebesar 3100-5500 Psi dengan elongasi sebesar 100\%. HDPE memiliki sifat bahan yang lebih keras, kuat, buram, dan lebih tahan terhadap suhu yang tinggi. HDPE mempunyai sedikit cabang, yang membuat HDPE memiliki ikatan intermolecular dan kekuatan tarik yang lebih besar dari LDPE. HDPE juga lebih keras dan opak, dan tahan temperatur tinggi. Meskipun memiliki kekuatan mekanik yang tinggi plastik ini tidak dapat didegradasi oleh lingkungan, untuk mengatasi masalah tersebut dilakukan pembuatan plastic biodegradable dengan mencampurkan plastik sintetis dengan polimer alam. Polimer alam memiliki beberapa kelemahan diantaranya sifat mekanik yang rendah, tidak tahan pada suhu tinggi, dan getas. Oleh karena itu pencampuran antara plastik sintetis dengan polimer alam diharapkan menghasilkan plastik yang memiliki sifat mekanik yang tinggi, dan mampu terurai oleh mikroorganisme (Inggaweni dan Suyatno, 2015).

Batang pisang merupakan limbah pertanian yang belum banyak dimanfaatkan. Sekarang ini serat batang pisang mulai diperhatikan oleh peneliti sebagai serat pakaian dan juga kertas, namun pemanfaatannya belum optimal. Selain itu juga banyak dimanfaatkan sebagai pintalan benang untuk kain rajut, interior mobil, furniture, dan kontruski ringan. Hal ini berarti, jika limbah batang pisang bisa termanfaatkan dengan baik, maka masalah limbah menjadi berkurang, 
serat batang pisang memiliki berat jenis $0,29 \mathrm{gram} / \mathrm{cm}^{3}$ dengan ukuran panjang serat 4,2 - 5,46 mm dan kandungan lignin 33,51\% (Khotimah dkk, 2015).

Umemura, (2006) menyebutkan bahwa pemanfaatan bahan baku dari alam daripada bahan baku sintetis merupakan isu lingkungan yang sudah lama berkembang. Hal ini berkaitan dengan beberapa kelebihan bahan baku alam seperti lebih ramah lingkungan dan potensinya yang cukup banyak dan dapat diperbaharui. Aini dan Indriati (2007) menggunakan zeolit sebagai pengisi kertas untuk menggantikan kaolin. Chen, dkk (2011) menambahkan zeolit pada sisi luar karton bergelombang sehingga karton lebih tahan terhadap kelembaban dan membantu sisi dalam bertahan lebih lama. Zeolit adalah nama umum untuk kelompok zeolit yang mana kristal- kristalnya merupakan aluminosilikat logam alkali dan alkali tanah yang mengandung air. Zeolit adalah zat berpori dengan pori-pori berskala nanometer (Mc.Bain, 1932). Penelitian Serat Batang Pisang dan Zeloit ini dilakukan untuk mendapatkan data tentang sifat-sifat mekanis dengan melakukan uji struktur serta uji tarik sebagai pertimbangan utama dalam pemilihan untuk bahan dasar alternatif pengganti serat sintetis sehingga terciptanya komposit baru yang dapat digunakan dalam industri khususnya dibidang otomotif interior mobil khususnya dashboard.

Penelitian perlakuan alkali juga pernah dilakukan oleh Amin.M dan Raharjo.S (2012) Perlakuan alkali serat rambut dilakukan guna menghilangkan lapisan minyak pada bagian luar rambut manusia. Lapisan minyak pada rambut tersebut akan menghalangi gaya ikat antara matrik dan penguatnya sehingga mechanical properties komposit akan rendah. Sehingga sebelum serat rambut dipergunakan sebagai penguat pada matrik epoxy terlebih dahulu dilakukan perlakuan alkali serat. Perlakuan alkali serat dilakukan dengan melakukan perendaman serat kedalam 5\% larutan $\mathrm{NaOH}$ selama (0, 30, 60, 90 dan 120) menit. Hasil penelitian pengaruh perlakuan alkali serat rambut manusia yaitu dengan bertambahnya waktu perendaman serat rambut didalam larutan $5 \% \mathrm{NaOH}$ akan meningkatkan harga tegangan tarik, regangan dan modulus elstisitas. Perendaman serat rambut selama 60 menit menunjukkan harga yang optimum untuk tegangan tarik dan regangan yaitu 28,862 $\mathrm{MPa}$ dan $0,18 \%$. Pada serat rambut yang tidak dilakukan perlakuan alkali memiliki mechanical bending yang lemah karena ikatan 
antara serat dengan matrik tidak dapat sempurna karena terhalang oleh adanya lapisan minyak pada rambut manusia. Dengan perlakuan alkali serat untuk menghilangkan lapisan minyak pada rambut agar dapat terjadi ikatan yang kuat antara serat dengan matriknya. Akan tetapi dengan perlakuan alkali yang terlalu lama akan menyebabkan rusaknya serat rambut (serat rambut menjadi rapuh). Sehingga komposit yang diperkuat dengan serat dengan waktu perendaman yang lebih lama menyebebkan turunnya kekuatan Tarik.

Berdasarkan Penelitian yang dilakukan oleh Amin.M dan Raharjo.S (2010) yang berjudul Pemanfaatan Limbah Serat Sabut Kelapa Sebagai Bahan Pembuat Helm Pengendara Kendaraan Roda Dua, dengan bahan serat sabut kelapa dan polyester dilakukan pembuatan spesimen dengan variasi jumlah spesimen sebanyak 5 yaitu spesimen 1 (27\% SSK-73\% PE), spesimen 2 (30\% SSK-70\% PE), spesimen 3 (36\% SSK-64\% PE), spesimen 4 (42\% SSK-58\% PE) dan spesimen 5 (60\% SSK$40 \% \mathrm{PE})$.

Hasil pengujian tarik yang diperoleh menunjukkan bahwa dengan bertambahnya fraksi volume serat akan meningkatkan tegangan tarik komposit serat sabut kelapa polyester. Berarti bahwa tegangan tarik dari serat sabut kelapa memiliki harga yang lebih tinggi dari matrik yaitu polyester. Tegangan tarik dari komposit serat sabut kelapa-polyester naik dengan naiknya fraksi volume serat. Tegangan tarik yang paling optimum dimiliki oleh bahan komposit polyester yang diperkuat serat sabut kelapa dengan fraksi volume 60\% yaitu sebesar 14,7 MPa. Hal ini menunjukkan bahwa fraksi volume tersebut merupakan fraksi volume yang paling efektif untuk meningkatkan kekuatan komposit berpenguat serat sabut kelapa. Pada komposit dengan serat sabut kelapa dengan fraksi volume yang lebih sedikit cenderung lebih rendah tegangan tariknya karena semakin sedikitnya reinforced (penguat) pada komposit tersebut. Sehingga semakin mudah mengalami putus apabila mengalami pembebanan dari pada komposit dengan fraksi volume yang semakin banyak. 


\section{METODE PENELITIAN}

\section{Bahan}

Bahan yang digunakan dalam penelitian adalah sebagai berikut:

\section{a. HDPE}

HDPE merupakan polimer polyethylene yang memiliki struktur rantai lurus. Proses pembuatan rantai dari plastik HDPE dilakukan pada proses dengan tekanan rendah. HDPE mempunyai sifat kristalinitas yang lebih tinggi dan kaku apabila dibandingkan dengan LDPE (Nasution, 2011).

b. Serat Batang Pisang

Serat merupakan ukuran panjang yang relatif jauh lebih besar dari pada ukuran lebarnya, begitupun serat pelepah pisang. Serat batang pisang diperoleh dari batang semu pisang. Batang semu ini terbentuk dari pelepah daun panjang yang saling menelungkup dan menutupi dengan kuat dan kompak sehingga bisa berdiri tegak seperti batang tanaman. Tinggi batang semu berkisar 3,5 - 7,5 meter tergantung jenisnya (Suyanti, 1993).

c. Zeolit

Zeolit merupakan mineral padat berpori yang memiliki kemampuan adsorpsi yang baik (Ansari dkk, 2014). Zeolit terdiri dari unsur alumina, silica dan sodium sebagai penyusun utamanya (Steen dkk, 2004). Kemampuan adsorpsi zeolit dimanfaatkan oleh beberapa peneliti untuk dimodifikasi menjadi membran. Membran zeolit merupakan membran anorganik yang stabil pada suhu yang tinggi (Barbosa, 2016).

\section{d. $\mathrm{NaOH}$}

Sifat alami serat adalah hyrophilic, yaitu suka terhadap air berbeda dari polimer yang hidrophilic. Pengaruh perlakuan alkali terhadap sifat permukaan serat alam selulosa telah diteliti dimana kandungan optimum air mampu direduksi sehingga sifat alami hidropholic serat dapat memberikan ikatan interfecial dengan matriks secara optimal (Bismarck dkk, 2002). Goud dan Rao (2011) juga membuktikan bahwa skin berbahan dasar serat yang diperlakukan dengan perendaman $\mathrm{NaOH}$ mempunyai nilai kekuatan tarik lebih besar dibanding tanpa perlakuan alkali. Menurut Yuliono dkk (2013) Bahwa sifat mekanis kekuatan tarik 
dapat ditingkatkan dengan perlakuan $\mathrm{NaOH}$ kadar 5\% selama 2 jam yaitu sebesar 35,404 MPa. NaOH seperti ditunjukan pada Gambar 7.

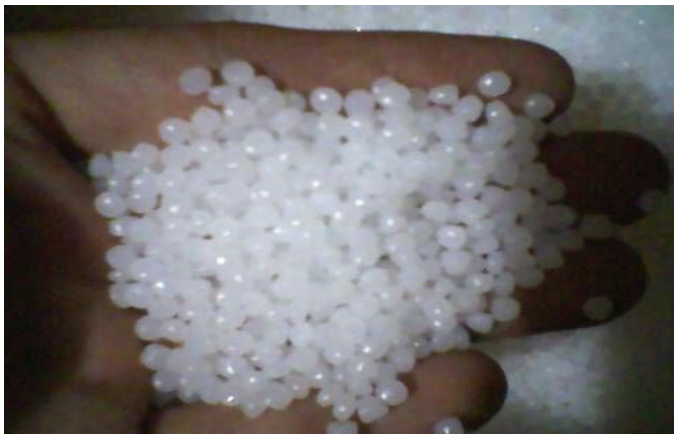

Gambar 4 HDPE

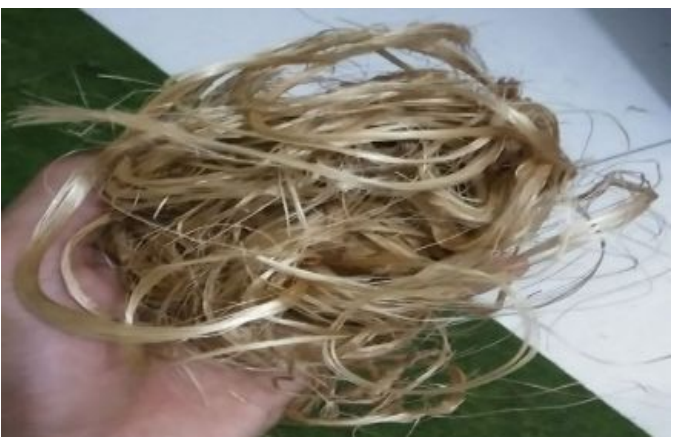

Gambar 5 Serat Batang Pisang

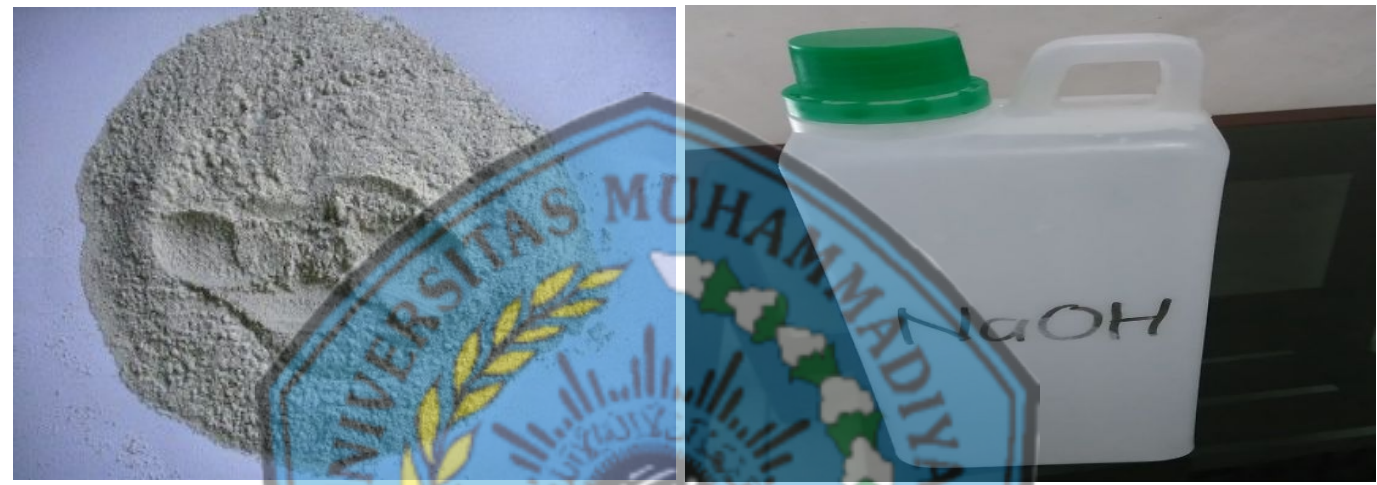

$$
\text { Gambar } 6 \text { Zeolit } \quad \text { Gambar } 7 \mathrm{NaOH}
$$

Alat

Alat-alat yang digunakan dalam penelitian adalah sebagai berikut:

1. Blender

2. Box atum

3. Ayakan

4. Sendok

5. Papan kayu

6. Timbangan digital
7. Gelas ukur

8. Gergaji pita

9. Gillette (silet)

10. Toples kaca

11. Penjepit specimen

12. Ragum penjepit
13. Oven

14. Gunting

15. Mesin Injection Molding

16. Mesin Uji Tarik

17. Mesin Uji SEM

\section{Prosedur Penelitian}

\section{Proses Pembuatan Serbuk HDPE}

Proses pembuatan serbuk dari biji plastik HDPE bertujuan supaya serbuk biji plastik HDPE sebagai matrik dengan serat batang pisang dan zeolit sebagai filler tercampur sempurna sehingga material komposit mempunyai hasil yang 
maksimal. Pembuatan serbuk HDPE ini dengan cara biji platik HDPE dihaluskan dengan bantuan alat blender.

\section{Proses Menghilangkan Lignin Serat Batang Pisang}

Persiapan bahan dalam proses pembuatan spesimen komposit ini dilakukan dengan mebersihkan kotoran yang menempel pada serat batang pisang, pembersihan serat ini bertujuan agar serat batang pisang terbebas dari zat-zat yang tidak terpakai pada proses pembuatan spesimen komposit serat batang pisang dan zeolit seperti lignin dan zat-zat lainnya yang terkandung dalam serat batang pisang. Proses selanjutnya memilih serat yang paling bagus (panjang), serat batang pisang selanjutnya akan melalui proses treatment atau perendaman serat terlebih dahulu sebelum proses pembuatan spesimen komposit HDPE yang diisi serat batang pisang dan zeolit.

Bahan kimia yang digunakan untuk proses treatment dalam pembuatan komposit ini menggunakan tarutan $\mathrm{NaOH}$ dan air sebagai pelarut dengan perbandingan 5\% $\mathrm{NaOH}$ dari $500 \mathrm{ml}$ air, yaitu dengan kadar $\mathrm{NaOH} 25 \mathrm{ml}$ dengan air $475 \mathrm{ml}$, setelah itu direndam di toples kaca selama 2 jam perendaman, setelah 2 jam perendaman serat batang pisang diangkat dan ditiriskan dan langsung dibilas menggunakan air yang mengalir bertujuan untuk menghilangkan sisa-sisa larutan $\mathrm{NaOH}$ yang masih menempel pada serat batang pisang. Serat batang pisang yang sudah dikeringkan dengan menggunakan oven sebelum pencampuran dengan serbuk HDPE untuk pembuatan spesimen komposit serat batang pisang dan zeolit. Selanjutnya serat batang pisang yang sudah dikeringkan akan dipotong dengan ukuran memendek sekitar $1 \mathrm{~mm}$ sampai $4 \mathrm{~mm}$ untuk proses pencampuran dengan serbuk HDPE dan zeolit.

\section{Proses Kalsinasi Zeolit}

Proses treatment zeolit, zeolit di panaskan ke dalam oven untuk menghilangkan kandungan air yang terdapat pada serbuk zeolit. Proses ini disebut proses kalsinasi dengan suhu konstan $500^{\circ} \mathrm{C}$ selama 3 jam.

\section{Injection molding}

injection molding adalah proses pembentukan suatu benda atau produk dari material plastik dengan bentuk dan ukuran tertentu yang mendapat perlakuan panas 
dan pemberian tekanan dengan menggunakan alat bantu berupa cetakan atau mold (Bryce, 1998). Injection molding sangat berguna sekali dalam melakukan peneletian ini dimana mesin ini berfungsi untuk melelehkan material spesimen komposit. Material yang meleleh akibat pemanasan heater kemudian panas tersebut disalurkan ke barell dan material yang sudah meleleh tersebut akan keluar kecetakan dengan proses penginjekan sehingga hasil sesuai yang diinginkan.

\section{Diagram Alur Penelitian}

Diagram alur penelitian dapat dilihat pada Gambar 8.

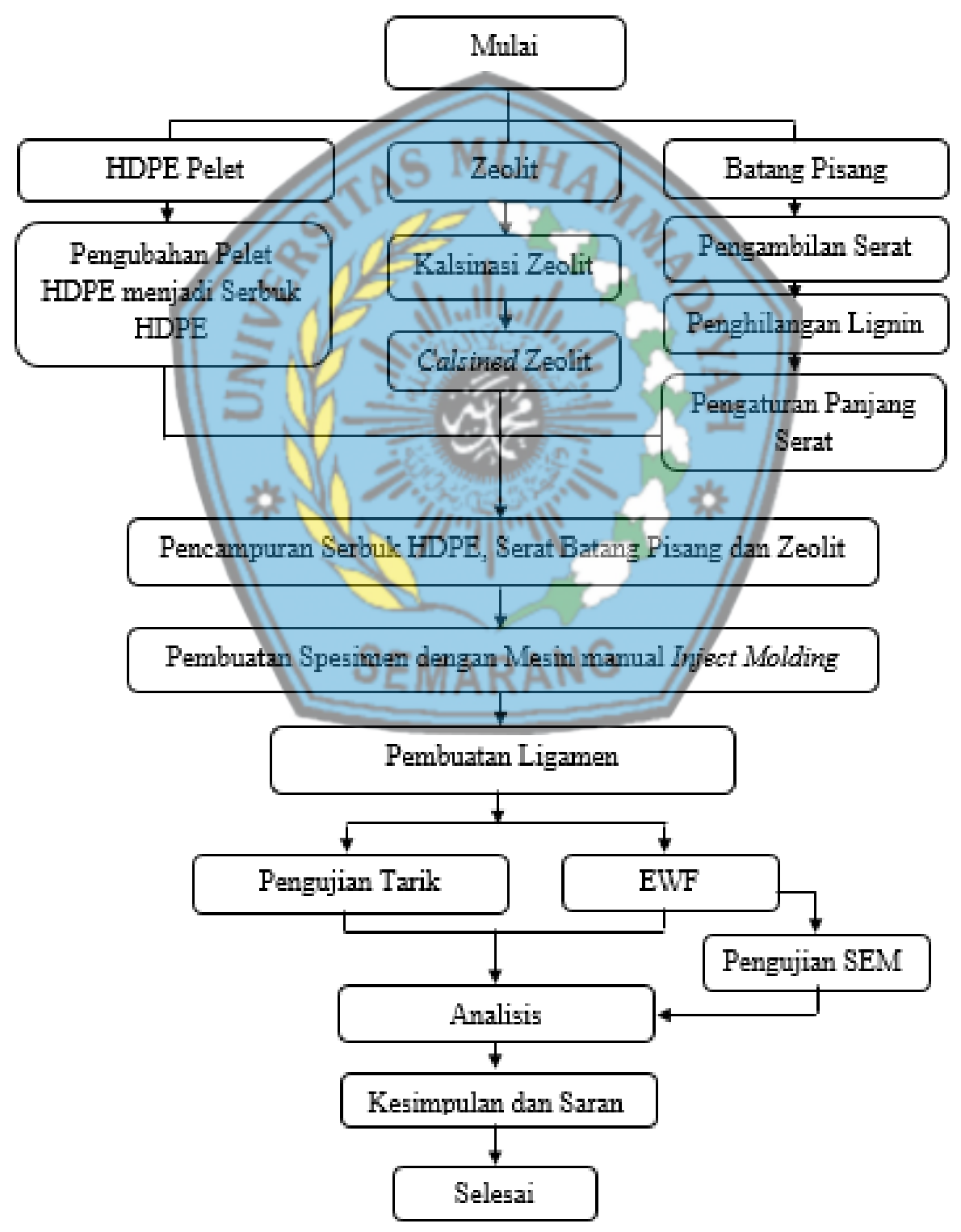

Gambar 8 Diagram Alur Peneletian 


\section{HASIL DAN PEMBAHASAN}

\section{Hasil Rata-Eata Pengujian Tarik Standart ASTM D 638-02}

Hasil rata-rata pengujian tarik spesimen komposit dengan standart pengujian ASTM D 638-02 dan standart DENT pada komposisi 0\% (HDPE Murni), serat $2 \%$ zeolit, serat $3 \%$ zeolit $2 \%$ dan serat $4 \%$ zeolit $1 \%$ dengan presentase HDPE tetap sebesar 95\%. Seperti yang ditampilkan pada tabel dan grafik pada Gambar 9.

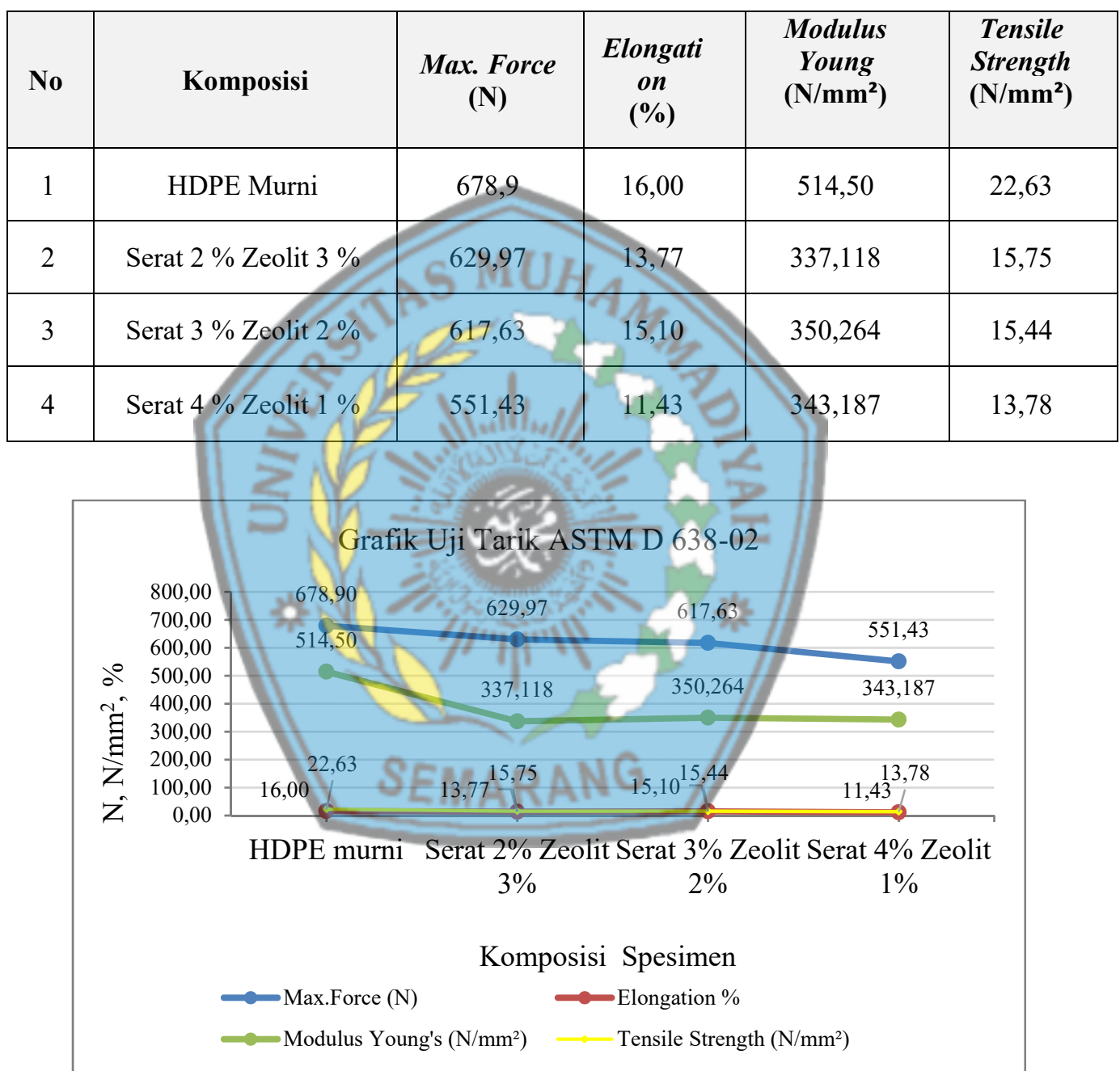

Gambar 9 Grafik Maximum Force, elongation, modulus Young dan tensile strength

Berdasarkan hasil rata-rata pengujian tarik dengan standart ASTM D 63802 didapat nilai tertinggi maximum force, elongation, modulus young, dan tensile strength terdapat pada HDPE murni dengan nilai maximum force 678,90 Newton, elongation $16 \%$, modulus young $514,50 \mathrm{~N} / \mathrm{mm}^{2}$ dan tensile strength 22,63 N/mm². 
2. Hasil Rata-rata Pengujian Tarik Standart DENT

\begin{tabular}{|c|c|c|c|c|}
\hline $\begin{array}{c}\text { Fraksi } \\
\text { Komposit }\end{array}$ & Ligamen & $\begin{array}{c}\text { Max. Force } \\
\text { (N) }\end{array}$ & $\begin{array}{c}\text { Elongation } \\
(\%)\end{array}$ & $\begin{array}{c}\text { Modulus } \\
\text { Young } \\
\left(\mathrm{N} / \mathrm{mm}^{2}\right)\end{array}$ \\
\hline \multirow{3}{*}{ HDPE Murni } & 6 & 341 & 26,12 & 902,432 \\
\hline & 8 & 499,1 & 35,01 & 994,402 \\
\hline & 10 & 521,7 & 56,07 & 1006,499 \\
\hline \multirow{3}{*}{$\begin{array}{l}\text { Serat 2\% } \\
\text { Zeolit 3\% }\end{array}$} & 6 & 211 & 7,01 & 302,843 \\
\hline & 8 & 319,8 & 12,31 & 531,979 \\
\hline & 10 & 406,1 & 8,27 & 807,905 \\
\hline \multirow{3}{*}{$\begin{array}{l}\text { Serat 3\% } \\
\text { Zeolit 2\% }\end{array}$} & 6 & 217,833 & 14,09 & 539 \\
\hline & 8 & 309,233 & 7,59 & 914,749 \\
\hline & 10 & 406,7 & 7,36 & 858,823 \\
\hline \multirow{3}{*}{$\begin{array}{l}\text { Serat 4\% } \\
\text { Zeolit 1\% }\end{array}$} & 6 & 239,166 & 9,93 & 742,145 \\
\hline & 8 & 283,366 & 10,24 & 792,329 \\
\hline & 10 & 410,37 & 8,07 & 1115,778 \\
\hline
\end{tabular}

Hasil rata - rata dari pengujian tarik dalam penelitian spesimen komposit serat batang pisang dan zeolit, seperti ditampilkan pada Gambar 10, 11 dan 12.

a. Grafik Pengujian Tarik Spesimen DENT

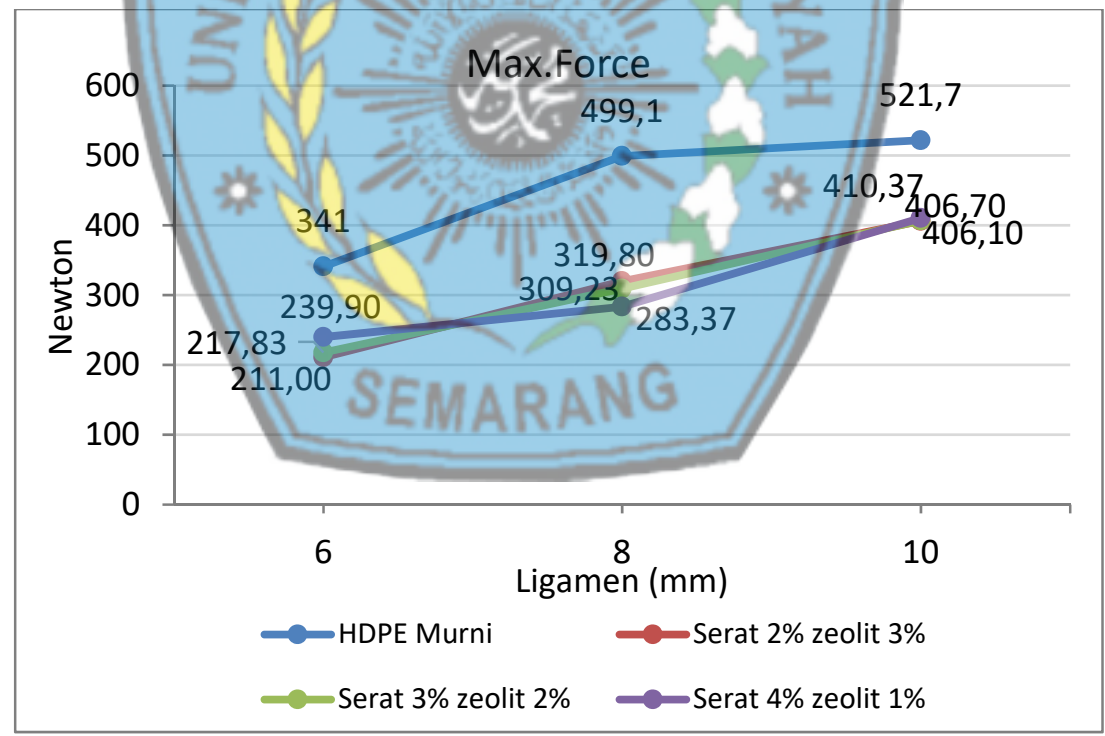

Gambar 10 Grafik Maximum Force 

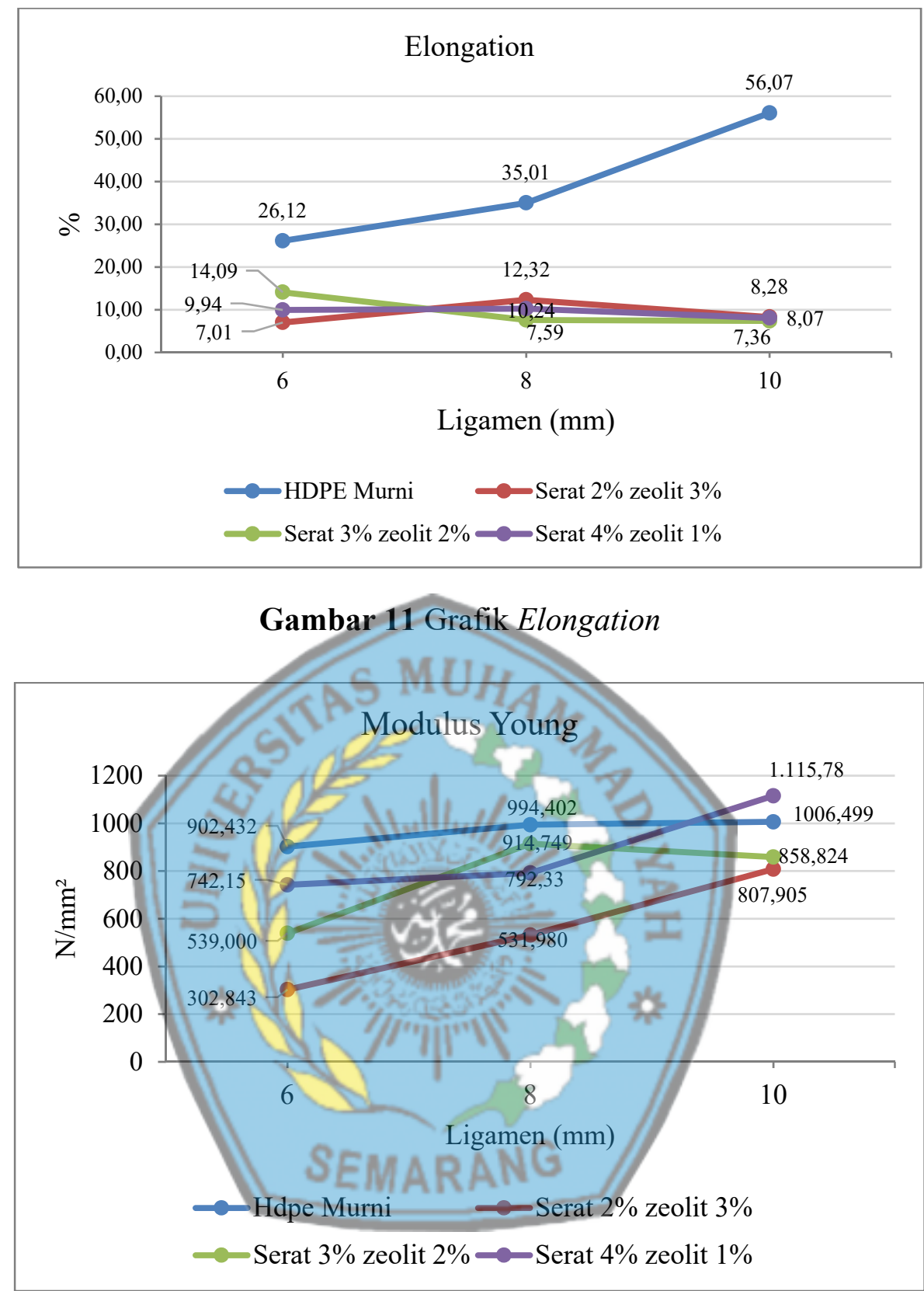

Gambar 12 Modulus Young

Berdasarkan hasil rata-rata pengujian tarik dengan standart DENT Dapat disimpulkan bahwa nilai tertinggi gaya maksimum, elongation dan modulus Young pada masing-masing lebar ligamen terdapat pada spesimen uji Tarik HDPE murni.

3. Energi Fracture Komposit HDPE Yang Diisi Serat Batang Pisang dan Zeolit

Hasil rata - rata yang didapat untuk energi fracture komposit 0\% (HDPE Murni), serat $2 \%$ zeolit $3 \%$, serat $3 \%$ zeolit $2 \%$, dan serat $4 \%$ zeolit $1 \%$ sebagaimana ditunjukan pada grafik seperti yang ditampilkan pada Gambar 13. 


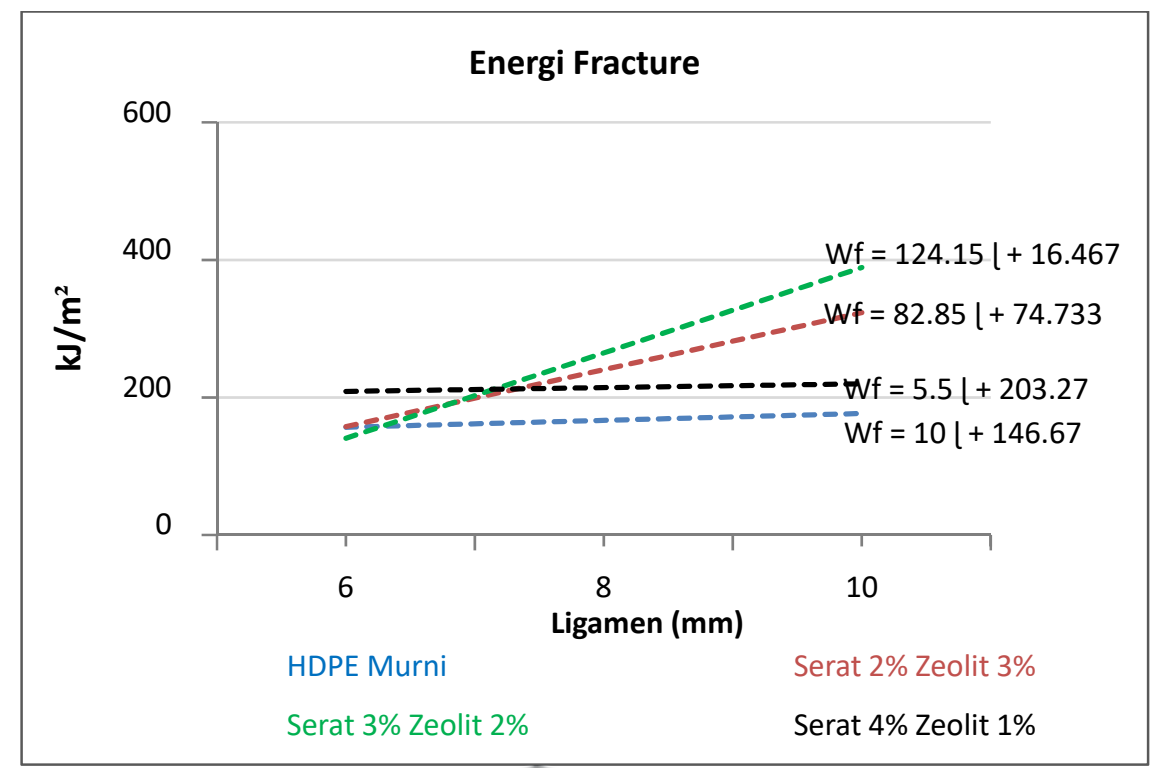

Gambar 13 Energi Fracture

Nilai Energi Fracture yang didapat dari spesimen dengan ligamen $6 \mathrm{~mm}, 8$ $\mathrm{mm}$, dan $10 \mathrm{~mm}$ dari komposisi 0\% serat dan zeolit (HDPE murni) dengan $W_{f}=10$ $l+146,67$ dari hasil tersebut kerja dari essensial patah spesifik (We) untuk komposisi serat dan zeolit 0\% (HDPE murni) adalah $146,67 \mathrm{~kJ} / \mathrm{m}^{2}$ sedangkan nonessensial patah spesifik ( $\beta w p$ ) adalah $10 \mathrm{~kJ} / \mathrm{m}^{2}$. Hasil rata - rata yang didapat untuk energi fracture pada spesimen komposit serat 2\% zeolit 3\% diperoleh nilai untuk $W_{f}=82,85\lfloor+74,733$ dengan nilai $\beta w p($ non - essensial kerja) dengan hasil rata rata $82,85 \mathrm{~kJ} / \mathrm{m}^{2}$ serta untuk nilai We (essensial Kerja) dengan hasil rata - rata yaitu $74,733 \mathrm{~kJ} / \mathrm{m}^{2}$.

Energi Fracture spesimen komposit serat batang pisang 3\% zeolit 2\% diperoleh hasil rata - rata hubungan linier adalah $W_{f}=124,15\lfloor+16,467$ dengan nilai ßwp (non - essensial patah) sebesar $124,15 \mathrm{~kJ} / \mathrm{m}^{2}$ dan untuk nilai We (essensial patah) sebesar 16,467 kJ/m². Energi Fracture spesimen komposit serat batang pisang $4 \%$ zeolit $1 \%$ diperoleh hasil rata - rata hubungan linier adalah $W_{f}$ $=5,5\left\lfloor+203,27\right.$ dengan nilai $\beta w p$ sebesar $5,5 \mathrm{~kJ} / \mathrm{m}^{2}$ dan untuk nilai We sebesar $203,27 \mathrm{~kJ} / \mathrm{m}^{2}$. 


\section{Nilai We dan $\beta w p$}

Nilai We (Essensial kerja patahan) tertinggi terdapat pada komposit dengan kandungan serat 4\% zeolit $1 \%$ dengan nilai $203,27 \mathrm{~kJ} / \mathrm{m}^{2}$ dibandingkan dengan campuran $0 \%$ (HDPE murni), serat $2 \%$ zeolit 3\%, dan campuran serat 3\% zeolit 2\% sebagaimana ditunjukan pada Gambar 14.

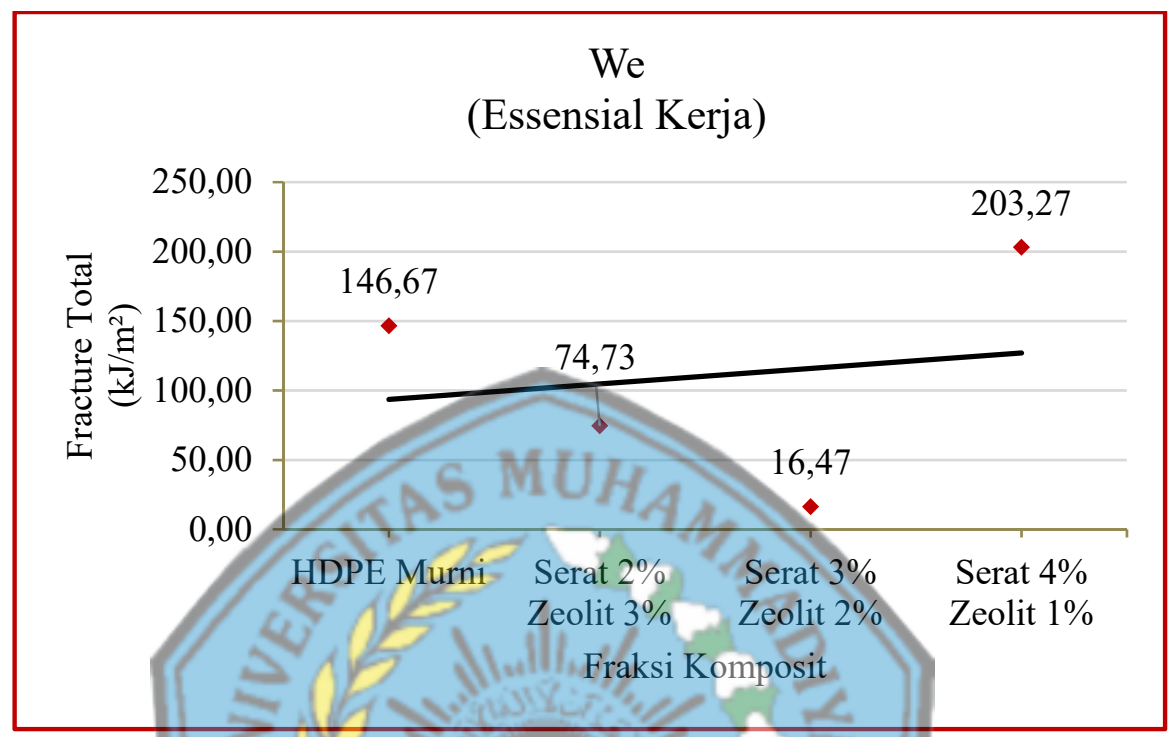

Gambar 14 Nilai Essensial Kerja (We)

Seperti pada Gambar 15 merupakan hasil rata rata dari Non- Essensial Kerja Spesifik ( $\beta w p)$, untuk komposit dengan komposisi serat 3\% zeolit 2\% merupakan nilai tertinggi $124,15 \mathrm{~kJ} / \mathrm{m}^{2}$ sedangkan komposisi serat $4 \%$ zeolit $1 \%$ merupakan hasil terendah dengan nilai $5,5 \mathrm{~kJ} / \mathrm{m}^{2}$, komposisi serat $2 \%$ zeolit $3 \%$ dengan nilai rata-rata $82,85 \mathrm{~kJ} / \mathrm{m}^{2}$ dan komposisi serat zeolit $0 \%$ (HDPE murni) dengan nilai $10 \mathrm{~kJ} / \mathrm{m}^{2}$.

\section{UJI SEM}

Uji SEM adalah seebuah pengujian yang bertujuan untuk mengetahui kandungan-kandungan dari sebuah material seperti kandungan morfologi, model struktural, dan interface khususnya pada spesimen komposit serat batang pisang sebagai filler, zeolit sebagai pengisi dan HDPE sebagai matrik. Dalam penelitian ini hasil uji SEM dapat dilihat pada Gambar 16. 

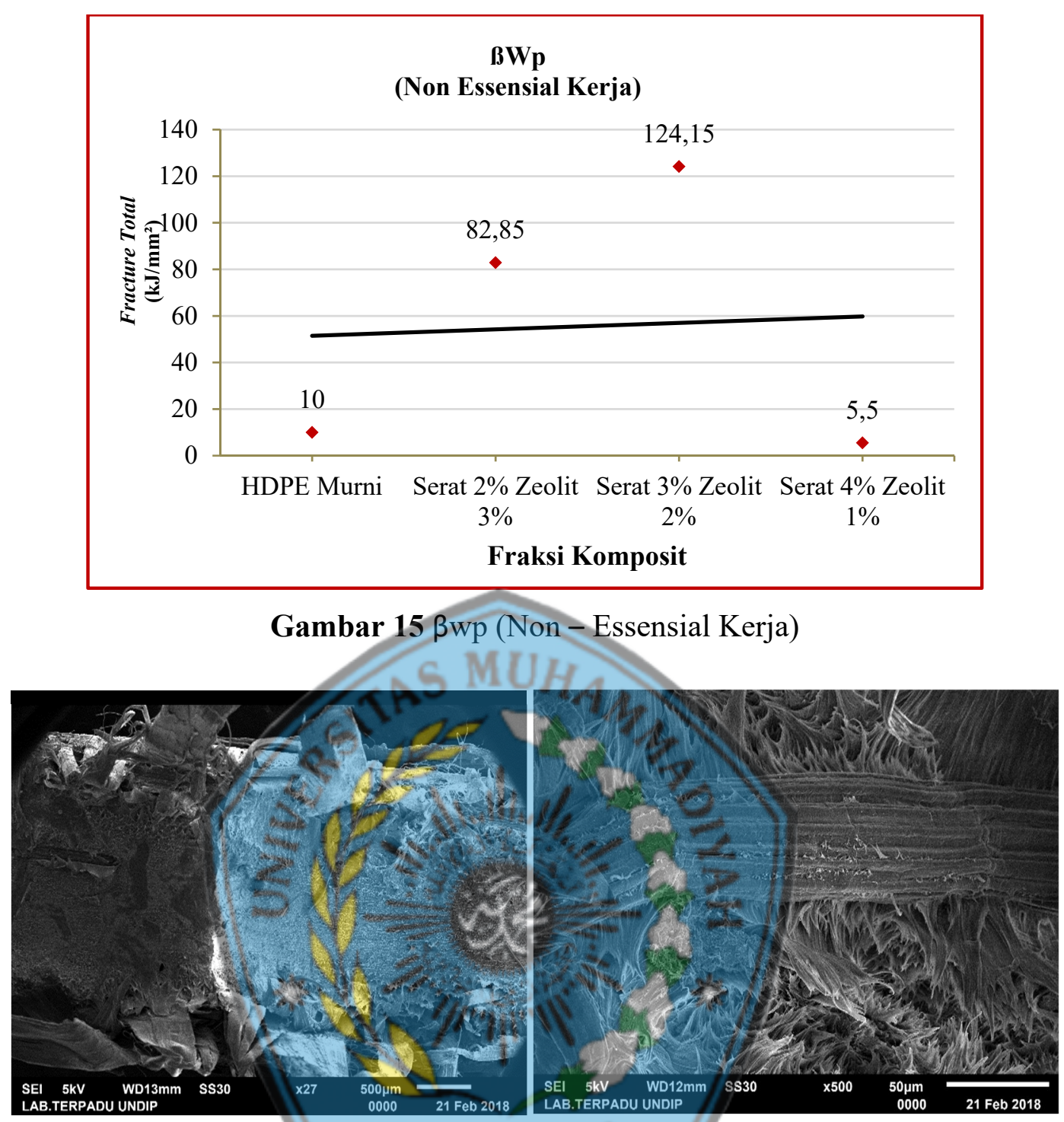

1. Sisi Bagian Keseluruhan
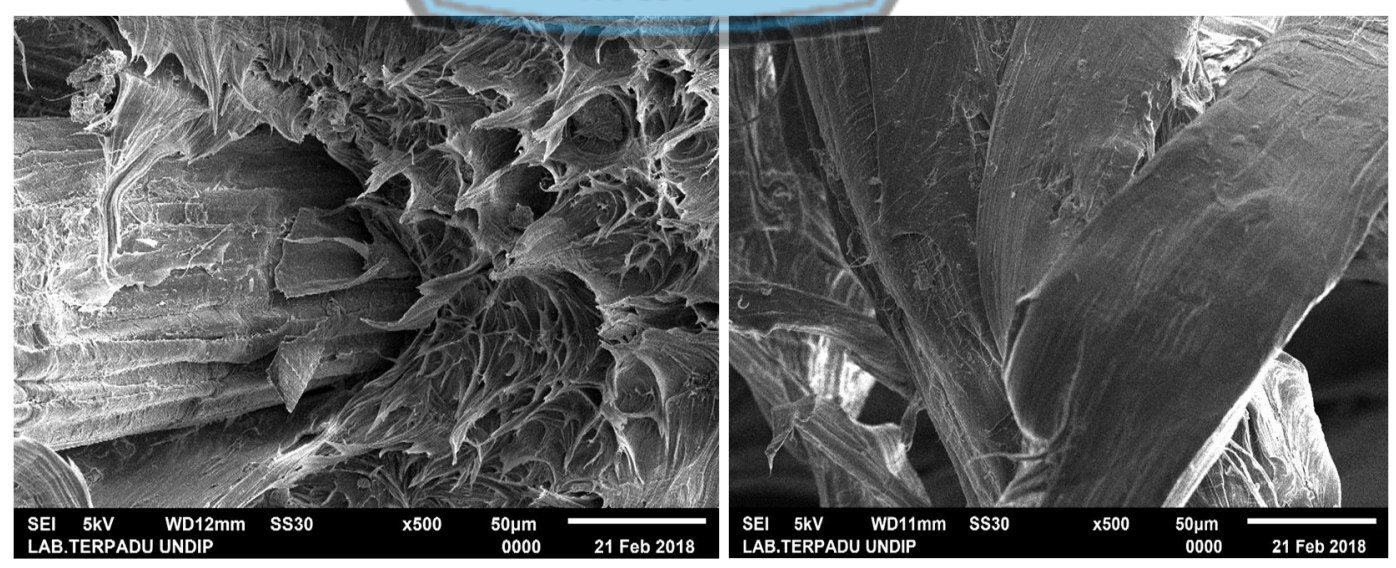

3. Sisi Bagian Tepi

4. Sisi Bagian Luar (Sisa patahan)

Gambar 16 Hasil Pengujian SEM 


\section{Sisi Bagian Keseluruhan 1}

Hasil yang didapat pada proses pengujian SEM yang ditunjukan pada Gambar 16 (1) dengan pembesaran 27 x dalam pengujiannya. Pengujian SEM menunjukan morfologi permukaan dari sisi bagian keseluruhan pada sisi saat spesimen putus dari hasil pengujian tarik, dalam pengujian ini terlihat sisa hasil patahan saat proses pengujian tarik yang tercampur oleh serat batang pisang dan zeolit.

\section{Sisi Bagian Tengah 2}

Sempel pengujian SEM yang di tunjukan pada Gambar 16 (2) Sempel pengujian SEM menunjukan bahwa pencampuran serat dan zeolit merata dan tataletak serat tidak teratur sehingga mengakibatkan letak serat tidak searah dapat dilihat dengan garis - garis pada morfologi permukaan dari hasil sisa pengujian tarik dengan pembesaran $500 \mathrm{x}$ dengan WD atau Working Distance jarak antar detektor dengan sampel yaitu $12 \mathrm{~mm}$. Hasil yang didapat menunjukan morfologi dari permukaan pada pencampuran HDPE, serat batang pisang dan zeolit.

\section{Sisi Bagian Tepi 3}

Sampel pengujian SEM dilakukan pada penelitian spesimen komposit serat batang pisang dan zeolit dapat dilihat hasil dari pengujian dengan garis - garis pada morfologi permukaan dari hasil sisa pengujian tarik dengan pembesaran $500 \mathrm{x}$ dengan WD atau Working Distance jarak antar detektor dengan sampel yaitu 12 mm. Hasil yang didapat menunjukan morfologi terlihat serat batang pisang mengalami perpatahan saat pengujian tarik sebagaimana ditunjukan pada Gambar $16(3)$.

\section{Sisi bagian luar (Sisa patahan) 4}

Pengujian SEM dengan menggunakan pembesaran $500 \mathrm{x}$ dan WD (Working Distance), morfologi dari permukaan yang dapat dilihat permukaan komposit sisa dari pengujian tarik memiliki perpanjangan antar serat batang pisang merata dan saling mengikat satu dengan yang lain, terlihat sisa dari perpanjangan komposit pada saat dilakukan pengujian tarik sebagaimana ditunjukan pada Gambar 16 (4). 


\section{KESIMPULAN}

Setelah dilakukan penelitian komposit serat batang pisang dan zeolit dengan komposisi $0 \%$ (HDPE murni), komposisi serat 2\% zeolit 3\%, serat 3\% zeolit 2\%, dan serat 4\% zeolit 1\% hasil pengujian tarik dengan standart ASTM D 638-02 HDPE Murni untuk gaya maksimum diperoleh nilai 678,9 N, elongation diperoleh $16,0 \%$, modulus Young dengan nilai $514,50 \mathrm{~N} / \mathrm{mm}^{2}$ dan tensile strength 22,63 $\mathrm{N} / \mathrm{mm}^{2}$. Pada komposisi serat 2\% zeolit 3\% didapat gaya maksimum 629,97 N, elongation 13,77\%, modulus Young 337,118 N/mm² dan tensile strength 15,75 $\mathrm{N} / \mathrm{mm}^{2}$. Pada komposisi serat 3\% zeolit 2\% didapat gaya maksimum 617,63 N, elongation 15,10\%, modulus Young 350,264 N/mm². dan tensile strength 15,44 $\mathrm{N} / \mathrm{mm}^{2}$. Pada komposisi serat 4\% zeolit 1\% didapat gaya maksimum 551,43 N, elongation 11,43\%, modulus Young 343,187 N/mm² dan tensile strength 13,78 $\mathrm{N} / \mathrm{mm}^{2}$.

Energi fracture pada ligamen $6 \mathrm{~mm}, 8 \mathrm{~mm}$ dan $10 \mathrm{~mm}$ mendapatkan hasil rata-rata kekuatan tarik tertinggi pada spesimen komposit dengan komposisi serat $4 \%$ zeolit $1 \%$ dengan nilai $203,27 \mathrm{~kJ} / \mathrm{m}^{2}$, dapat disimpulkan komposit dengan campuran serat $4 \%$ zeolit $1 \%$ memiliki hubungan linier yang baik dibandingkan dengan komposit dengan komposisi serat dan zeolit lainnya.

\section{DAFTAR PUSTAKA}

Ansari, M., Aroujalian, A., Raisi, A., Dabir, B., \& Fathizadeh, M. 2014. Preparation and characterization of nano-NaX zeolite by microwave assisted hydrothermal method. Advanced Powder Technology, 25 (2), 722-727.

Amin. Muh \& Raharjo. S. 2010. Pemanfaatan Limbah Serat Sabut Kelapa Sebagai Bahan Pembuat Helm Pengendara Kendaraan Roda Dua. Prosiding Seminar Nasional UNIMUS. ISBN:978.979.704883.9. Program Studi teknik Mesin. Fakultas Teknik. Universitas Muhammadiyah Semarang.

Amin. Muh \& Raharjo. S. 2012. Pengembangan Bahan Alternatif Interior Dan Eksterior Otomotif Dengan Limbah Rambut Manusia. Universitas Muhammadiyah Semarang.

ASTM International. West Conshohocken, PA 19428-2959, ASTM D 638-02.

"Standard Test Method for Tensile Properties of Plastics" United States. 
Barbosa, G. P., Debone, H. S., Severino, P., Souto, E. B., \& Da Silva, C. F. (2016). Design and characterization of chitosan/zeolite composite films - Effect of zeolite type and zeolite dose on the film properties. Materials Science and Engineering $C$, 60, 246-254.

Bismarck A, Askargorta IA, Lamphe T, Wielaye B, Stamboulis A, Skenderovich I, Limbach HH. 2002, "Surface Characterization of Flax, Hemp and Cellulose Fibres: Surface Properties and the Water Uptake Behavior", Polymer Composite Vol 23, no. 5

Clareyna Eqitha Dea, Lizda Johar Mawarani, 2013. Pembuatan dan Karakteristik

Komposit Polimer Berpenguat Bagasse, Institut Teknologi Sepuluh Nopember (ITS), ISSN: 2337-3539.

Goud, Govardhan.; and Rao, R,N. 2011. "Effect of Fibre Content and Alkali Treatment on Mechanical Properties of Roystonea Regia-Reinforced Epoxy Partially Biodegradable Composites" Bulletin of Materials Science.Vol. 34. No. 7, December 2011, pp. 1575-1581.

Inggaweni Luy, Suyatno, 2015, Karakterisasi Sifat Mekanik Plastik Biodegradable dari Komposit HDPE dan PatiKulit Singkong, UniversitasNegri Surabaya, ISBN: 978-602-0951-05-8.

Kartini, Ratni. dkk. 2002. Pembuatan dan Karakterisasi Komposit Polimer berpenguat Serat Alam. Jurnal Sains Material Indonesia, Vol.3, No.3 hal: 3038. ISSN :1411-1098.

Kusharjanta Bambang Dan Dody Ariawan. 2008. "Kajian Pengaruh Faktor Panjang Ukur Pada Metode Essential Work Of Fracture Terhadap Hasil Pengujian Ketangguhan Retak Polypropylene”. Seminar Nasional Aplikasi Sains dan Teknologi - IST AKPRIND Yogyakarta.

Khotimah Khusnul, Susilawati, Harry Soeprianto 2015. Sifat Penyerapan Bunyi Pada Komposit Serat Batang Pisang (SBP) - Polyester. Jurnal Penelitian Pendidikan IPA (JPPIPA), e-ISSN: 2407-795X, Universitas Mataram.

Mc.Bain, J.W, (1932), “The Sorption of Gases and Vapors by Solids”, Chapter 5, Rutledge and Sons, London.

Nasution, A. 2011. Pembuatan Papan Partikel Komposit Polietilena Kerapatan Rendah Daur Ulang Dan Tandan Kosong Kelapa Sawit. 
Suyanti, Supriyadi dan Ahmad. 2008. Pisang Edisi Revisi: Budidaya, Pengelolaan dan Prospek Pasar. Jakarta : Penebar Swadaya.

Steen, E. Van, Callanan, L. H., \& Division, C. 2004. Synthesis and characterization of the nanocrystalline zeolite ZSM-35.pdf, 154(1), 189-194.

Sears, Zemansky. (2002). Fisika Untuk Universitas. Jilid 2. Erlangga. Jakarta.

Stevens, M. P. 2001. Kimia Polimer, Edisi Pertama. Jakarta: Pradnya Paramita.

Yuliono E. N, Agus Yulianto, dan M. P. Aji. “Kuat Tarik Tali Berbahan Dasar Serat Batang Pisang”. Jurnal Fisika Vol. 3 No. 1, Mei 2013, FMIPA UNNES.

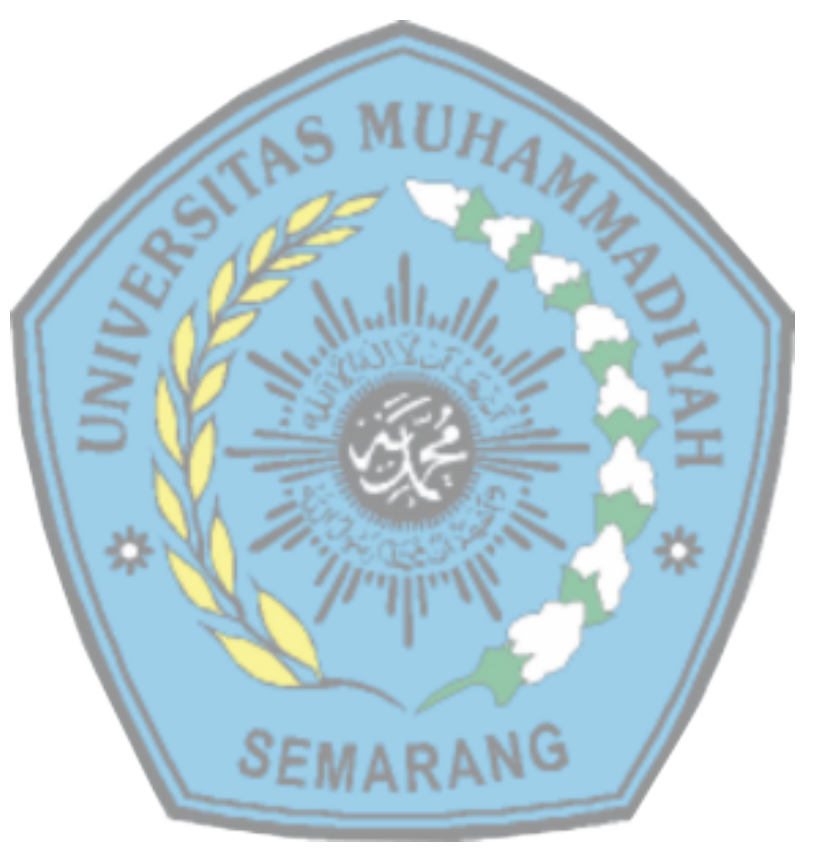

PENULIS:

\section{HARDIMAN NURCAHYANTO}

PT. Ungaran Sari Garment, J1 P Diponegoro No 235 Ungaran Kab Semarang 50512

Email: hardimann.c@gmail.com 